\title{
Immunocastration on performance and meat quality of Bos indicus (Nellore) cattle under
}

\section{different nutritional systems}

\author{
Rickyn Alexander Jacinto-Valderrama1 ${ }^{\oplus}$, Guilherme Sicca Lopes Sampaio ${ }^{3 \oplus}$, Maria Lucia Pereira Lima²®, Joslaine Noely dos Santos

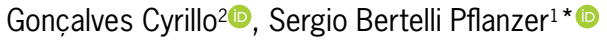

IUniversidade Estadual de Campinas/FEA - Depto. de Tecnologia de Alimentos, R. Monteiro Lobato, 80 - Cidade Universitária Zeferino Vaz - 13083-862 - Campinas, SP Brasil.

2Instituto de Zootecnia/Centro de Pesquisa em Bovinos de Corte, Av. Carlos Tonani, km 94 - 14174-000 - Sertãozinho, SP - Brasil.

3Universidade Estadual Paulista/FCA - Depto. de Melhoramento e Nutrição Animal, R. José Barbosa de Barros, 1780 - 18610-307 - Botucatu, SP - Brasil.

*Corresponding author <spflanzer@gmail.com>

Edited by: Pedro Esteves Duarte Augusto

Received May 20, 2019

Accepted August 01, 2019
ABSTRACT: The present study aimed to evaluate the effects of immunocastration on the animal growth, carcass traits, and meat quality of Nellore cattle receiving or not lonophore supplementation at pasture or pasture with concentrate (semi-feedlot). The first experiment (Pasture) was carried out during the rainy season, while the second (supplemented $=$ Semifeedlot) was conducted during the dry season. In each assessment, 60 males were allocated into three treatments, in a completely randomized design: non-castrated, immunocastrated (antigonadotropin-releasing hormone vaccine), and immunocastrated animals receiving ionophore. The highly energetic supplemented diet was prepared using $85 \%$ corn and $10 \%$ soybean meal at $1 \%$ body weight, while the ionophore was provided with salt containing $1,650 \mathrm{mg} \mathrm{kg}^{-1}$ of lasalocid. After slaughter, the carcasses were graded, and Longissimus thoracis et lumborum samples were collected for meat quality analysis. The non-castrated animals exhibited a more significant final body weight and hot carcass weight than those immunocastrated regardless of ionophore supplementation $(p<0.05)$. The carcasses of non-castrated animals had less fat cover and marbling than castrated animals. A high incidence of dark cutting beef was verified in non-castrated animals. The immunocastrated cattle produced tenderer beef, mainly at pasture rearing. In conclusion, regardless of production system or ionophore supplementation, immunocastration was an adequate choice to generate high-quality meat, since it increased marbling and improved beef tenderness. However, limitations regarding animal growth should be estimated.

Keywords: DFD, beef tenderness, marbling, grown performance, ionophores

\section{Introduction}

The traditional castration method of males consists of surgery, gonad removal, or rupture of the spermatic cord. These techniques lead to postoperative complications, labor costs, time expenditure, stress, decreased production, and problems regarding animal welfare (Needham et al., 2017). Therefore, immunocastration, a temporary castration method that blocks testosterone production, as in surgical castration but without adverse side effects, has been considered the optimal procedure to improve carcass and meat quality characteristics since it provides a more significant deposition of subcutaneous and intramuscular fat, improving beef quality.

In order to improve animal performance, regardless of its sexual status, growth promoters, such as ionophores, may be used to increase feed efficiency, enabling the animal to have a better use of ingested nutrients during feeding, which is observed by significant gains in body weight. The inhibitory effect of ionophores against Gram-positive bacteria affects ruminal fermentation, enhancing propionate concentration and reducing acetate and butyrate levels, which, in turn, decreases the availability of $\mathrm{H}^{+}$ions for methanogenic bacteria, reducing methane production. The reduction of energy loss in the form of methane contributes indirectly to more energy for the animal and greater availability of substrate for hepatic glucose production (Russel and Strobel, 1989).

Due to the lower growth efficiency of castrated animals, most Brazilian beef producers avoid castration, even knowing the problems that this procedure could bring to meat quality. Non-castration, associated to the use of zebu cattle, raised predominantly on pasture, leads to the production of low quality meat, mainly with lower intramuscular fat and consequently tougher. It is hypothesized that the use of a growth promoter, such as an Ionophore, in Immunocastrated animals can ensure animal growth performance comparable to noncastrated animals, without impacting meat quality of castrated animals.

To date, interactions between immunocastration technology, ionophore supplementation, and cattle finishing systems have not been described in the literature. Therefore, the objective of this study was to investigate the effects of ionophore application on performance, carcass characteristics, and meat quality of immunocastrated Nellore cattle finished at pasture or semi-feedlot.

\section{Materials and Methods}

All procedures in this study were conducted in accordance with the Brazilian Guidelines for the Care and Use of Animals for Scientific and Educational 
Purposes of National Council for Control of Animal Experimentation. The work was submitted to the Ethics Committee of Instituto de Zootecnia protocol number 192-14. The experimental portion involving the finishing phase of the animals was performed at Sertãozinho, in

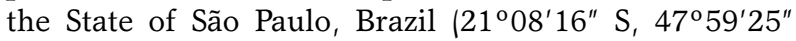
$\mathrm{W}$, altitude of $579 \mathrm{~m})$. Slaughter and carcass evaluations were carried out in a commercial slaughterhouse, under federal supervision, following sanitary and Animal Welfare standards. The meat quality analyses were conducted at the Meat Laboratory in Campinas, São Paulo, Brazil.

The research was divided into two experiments, characterized by two production systems: Pasture and Semi-feedlot. The first assessment was carried out during the summer (rainy season/7 Dec, 2015 to 27 June, 2016), in which the animals were finished at pasture and received supplementation using only mineral salt. The second (Semi-feedlot) was conducted during the winter (drought season/13 July to 8 Dec, 2016), where the animals received, in addition to pasture, supplementation with a protein-energetic ration. In each experiment, 60 non-castrated male Nellore bulls were used, divided into three treatments, according to sexual status and ionophore use: Immunocastrated, Immunocastrated + Ionophore, and Non-castrated.

An area of 30 ha of previously established pasture with Brachiaria brizantha c.v. Marandu was subdivided into 15 paddocks with 2 ha each, containing individual troughs for supplementation and drinkers. Prior to the distribution into each treatment, the animals were weighed for weight range categorization, keeping a maximum capacity of four bulls in each paddock. The statistical design consisted of randomized blocks. To measure the supplement intake (Pasture) or the proteinenergetic supplement intake (Semi-feedlot), each pen, housing four steers, was controlled weekly by weighing the total feed offered and leftovers, with five replicates per treatment per day.

\section{Experiment 1 - Pasture}

The immunocastrated animals received three doses of the anti-GnRH antigen vaccine (Zoetis Indústria de Produtos Veterinários Ltda, SP-Brazil). The first dose was given on 7 Dec, 2015 (beginning of the experiment), and the others were applied on 7 Jan, 2016, and 4 Feb, 2016. The mineralized salt, offered at will in collective troughs, comprised the following levels of minerals per $\mathrm{kg}$ of product: $\mathrm{Ca}-150 \mathrm{~g}, \mathrm{P}-60.0 \mathrm{~g}, \mathrm{Na}-110 \mathrm{~g}, \mathrm{~S}-10.0 \mathrm{~g}$, Ma - 5,000 mg, Cu - 1,000 mg, Fe - 1,200 mg, Mn - 1,000 mg , Co - 60.0 mg, I - 60.0 mg, Zn - 3,000 mg, Se - 10.0 mg, and a maximum of fluorine of $600 \mathrm{mg}$; which was supplied to the immunocastrated and non-castrated animals.

In the immunocastrated animals supplemented with lasalocid, mineralized salt contained $1.650 \mathrm{mg}$ of ionophore per $\mathrm{kg}$ of product. During the experiment, rainfall was normal and occurred during the early summer, from Dec 2015 until mid-Mar 2016. The average forage mass supplied at pasture was $4,309 \mathrm{~kg}$ of DM ha-1, with $45 \%$ of leaf blades. At the beginning of autumn, rainfall was interrupted, unexpectedly and atypically for that period, hindering the growth of pastures at the end of Mar and Apr. The low volumes of rain in May and June, in addition to the reduced temperatures, also hampered pasture growth. In autumn, the average forage mass was $2,760 \mathrm{~kg}$ of $\mathrm{DM} \mathrm{ha}^{-1}$ with $17 \%$ of leaf blades. The animals remained in the finishing phase for 203 days until slaughter.

\section{Experiment 2 - Semi-feedlot}

The immunocastrated animals received two doses of the anti-GnRH antigen vaccine, (Zoetis Indústria de Produtos Veterinários Ltda, SP, Brazil). The first dose was applied on 13 July, 2016 (beginning of the experiment), and the second, on 2 Sept, 2016. All animals in the Semi-feedlot system were pasture-grazed, in addition to protein-energetic supplementation (concentrate), in the proportion of $1 \%$ body weight. The concentrate was composed of $85 \%$ corn, $10 \%$ soybean meal, $2 \%$ urea, $1 \%$ calcium carbonate, and $3 \%$ mineral salt with or without lasalocid (10.0 mg lasalocid $\mathrm{kg}^{-1}$ mineral salt). At the end of the dry season, with the onset of rains, the raw urea material was added at a proportion of $1 \%$.

The experiment started during the dry season, when pastures were well-damaged due to the lack of rainfall at the end of the rainy season. The average forage mass was $2,830 \mathrm{~kg}$ of $\mathrm{DM} \mathrm{ha}{ }^{-1}$, with $16 \%$ of leaf blades. With the beginning of spring and return of the rainy season, an abundant pasture growth occurred at the end of the experiment, and, in Nov-Dec, the average forage supply was $4,467 \mathrm{~kg}$ of DM ha ${ }^{-1}$, with $57 \%$ of leaf blades. The animals remained in the finishing phase for 148 days until slaughter.

\section{Slaughter and carcass indicators}

After the finishing phase, the animals were weighed (final live weight) and sent to slaughter. Subsequently, the hot carcass weight, and fat covering were recorded, according to the Brazilian Bovine Carcass Classification System (MAPA, 2004). The carcasses were then sent to cooling, where they remained for $48 \mathrm{~h}$. Afterward, the carcasses were evaluated for physiological maturity and cut between the $12^{\text {th }}$ and $13^{\text {th }}$ ribs to evaluate the loin eye area, subcutaneous fat thickness, marbling, and color (Meat Evaluation Handbook-AMSA, 2001). Each left carcass side underwent the removal of a sample ( $10.0 \mathrm{~cm}$ ), which was boned, identified, vacuum-packed (50 $\mu \mathrm{m}$ thick, oxygen permeability of $20 \mathrm{~cm}^{3} \mathrm{~m}^{-2}, 24 \mathrm{~h}$, at $23^{\circ} \mathrm{C}$, and $75 \% \mathrm{RH}$ ), and sent to the Meat Laboratory in iceboxes.

\section{Meat quality analyses}

In the laboratory, each sample was cut into three $2.5 \mathrm{~cm}$-thick steaks. The first, still fresh, was initially used for instrumental color examination, followed by $\mathrm{pH}$ and moisture and the fat content analysis. The other two 
steaks were vacuum-packed and aged for 7 or $14 \mathrm{~d}$, at 2 $\pm 1{ }^{\circ} \mathrm{C}$ to determine shear force. When the desired aging period was completed, counted as the date of slaughter, the steaks were frozen until the shear force analysis was conducted. The samples were cleaned for subcutaneous fat and characterized regarding moisture contents by oven drying (AOAC, 1980) and intramuscular lipids by using the Bligh and Dyer (1959) method.

The $\mathrm{pH}$ was determined $72 \mathrm{~h}$ after slaughter using an MP125 Mettler Toledo penetration electrode, which was inserted into the center of the steaks /one measure per steak). Color measurements were performed in three different points on the freshly cut surface of one of the steaks, exposed to $4{ }^{\circ} \mathrm{C}$ for $1 \mathrm{~h}$ with a CM 508-d HunterLab portable spectrophotometer (MiniScanTMXE), in accordance to the specifications of the Guidelines for Meat Color Evaluation (AMSA, 1991), using a D-65 illuminant at $10^{\circ}$ observation angle.

For Warner Bratzler shear force (WBSF), samples were cooked, according to the AMSA (2015) procedures, in an electric oven $(6,000 \mathrm{~W})$, at $165^{\circ} \mathrm{C}$, until an internal temperature of $71{ }^{\circ} \mathrm{C}$ was reached. Following cooking, the steaks were cooled $\left(5^{\circ} \mathrm{C}\right)$ for $12 \mathrm{~h}$. Six cylinders of $1.27 \mathrm{~cm}$ in diameter were sampled, parallel to the longitudinal muscle fiber direction, using a coring cutter. The cylinders were immediately sheared into a texture analyzer (50 kg load cell), equipped with a $1.0 \mathrm{~mm}$-thick Warner-Bratzler blade, adjusted for a crosshead speed at $200 \mathrm{~mm} \mathrm{~min}^{-1}$ (AMSA, 2015).

\section{Statistical analysis}

The statistical analysis was conducted in a $2 \times 3$ factorial scheme, with two production systems and three types of treatment for animal performance information, carcass characteristics, and meat quality attributes (color and moisture and fat contents). In order to evaluate the weight loss due to cooking and shear force, a $2 \times 3 \times$ 2 factorial design was applied, with two production systems, three treatments, and two aging periods.
The analysis of variance (ANOVA) was performed to assess the primary factors and their interactions. When interaction was significant $(p<0.05)$, the means were compared using the Tukey Significant Difference test.

\section{Results}

\section{Animal performance}

During the Pasture experiment, no difference was detected for supplement intake $(p=0.82)$ between treatments. The average intake of mineralized salt was $103 \pm 5.2 \mathrm{~g} \mathrm{~d}^{-1}$ for immunocastrated animals, $112 \pm$ $7.3 \mathrm{~g} \mathrm{~d}^{-1}$ for non-castrated cattle, and $106 \pm 6.7 \mathrm{~g} \mathrm{~d}^{-1}$ for immunocastrated supplemented with lasalocid. Thus, the average lasalocid intake was $175 \mathrm{mg}$ per animal $\mathrm{d}^{-1}$. Moreover, in the Semi-feedlot experiment, no difference was detected for concentrate intake $(p=0.91)$ between treatments. The average of concentrate intake per animal was $5.20 \pm 0.21 \mathrm{~kg} \mathrm{~d}^{-1}$ for the immunocastrated group, $5.21 \pm 0.20 \mathrm{~kg} \mathrm{~d}^{-1}$ for non-castrated cattle and $5.24 \pm$ $0.27 \mathrm{~kg} \mathrm{~d}^{-1}$ for immunocastrated bovines supplemented with lasalocid. In the immunocastrated treatment with lasalocid, the average sodium lasalocid consumption was $240.2 \mathrm{mg}$ per animal d $\mathrm{d}^{-1}$.

There was no interaction between production system and treatment for initial live weight (ILW), nor was there an effect concerning treatment $(p>0.05)$. However, animals in Semi-feedlot were heavier at the beginning of the project when compared to animals in the Pasture experiment. The Semi-feedlot group contained heavier animals due to the differences in availability of animals at the moment of their acquisition (Table 1). There was an interaction between production system and treatment (Figure 1A) on the final live weight (FLW). In the Pasture experiment, non-castrated animals were heavier $(p<0.05)$ than immunocastrated ones, regardless of the ionophore treatment. However, in the Semi-feedlot experiment, no difference was observed for FLW between the different treatments $(p>0.05$; Figure $1 \mathrm{~A})$.

Table 1 - Effect of the Production System and type of Treatment on the beef carcass characteristics: Live Weight, Hot Carcass Weight (HCW), Dressing Percentage (DP), Ossification, Rib Eye Area (REA), Subcutaneous Fat Thickness (FT), Marbling Level, and ultimate pH of the Longissimus thoracis et lumborum muscle.

\begin{tabular}{|c|c|c|c|c|c|c|c|c|c|}
\hline & \multicolumn{2}{|c|}{ Production system } & \multicolumn{3}{|c|}{ Treatment } & \multirow[b]{2}{*}{ SEM } & \multicolumn{3}{|c|}{$p$ value } \\
\hline & Pasture & Semi-feedlot & Immunocastrated & $\begin{array}{l}\text { Immunocastrated + } \\
\text { lonophore }\end{array}$ & Non-castrated & & $\begin{array}{l}\text { Production } \\
\text { system }\end{array}$ & Treatment & $\begin{array}{l}\text { Prod. System } \times \\
\text { Treatment }\end{array}$ \\
\hline Initial live weight (kg) & $361.9^{b}$ & $375.3^{a}$ & 367.7 & 369.5 & 368.8 & 2.5 & 0.0007 & 0.93 & 0.65 \\
\hline Final live weight (kg) & 519.9 & 516.2 & $508.4^{b}$ & $510.9^{b}$ & $535.8^{\mathrm{a}}$ & 3.0 & 0.365 & 0.0001 & 0.014 \\
\hline HCW (kg) & 274.3 & 280.3 & $273.6^{b}$ & $275.9^{b}$ & $283.3^{\mathrm{a}}$ & 1.6 & 0.104 & 0.037 & 0.043 \\
\hline DP (\%) & $52.8^{b}$ & $54.5^{\mathrm{a}}$ & 53.9 & 54.1 & 53.1 & 0.4 & 0.017 & 0.374 & 0.872 \\
\hline Ossification ${ }^{1}$ & A90.3a & A73. $1^{\mathrm{b}}$ & A74. $6^{\mathrm{b}}$ & $A 72.8^{b}$ & A98.9a & A4.0 & 0.022 & 0.009 & 0.862 \\
\hline $\mathrm{REA}\left(\mathrm{cm}^{2}\right)$ & 66.3 & 67.0 & 65.5 & 65.8 & 68.8 & 1.3 & 0.622 & 0.137 & 0.317 \\
\hline FT (mm) & 2.7 & 2.3 & $2.7^{a}$ & $2.8^{\mathrm{a}}$ & $2.1^{\mathrm{b}}$ & 0.1 & 0.14 & 0.033 & 0.023 \\
\hline Marbling ${ }^{2}$ & $1.7^{\mathrm{a}}$ & $1.1^{\mathrm{b}}$ & $1.5^{\mathrm{a}}$ & $1.4^{\mathrm{a}}$ & $1.2^{\mathrm{b}}$ & 0.1 & 0.000001 & 0.036 & 0.041 \\
\hline $\mathrm{pH}$ & 5.7 & 5.6 & $5.6^{\mathrm{b}}$ & $5.6^{\mathrm{b}}$ & $5.8^{\mathrm{a}}$ & 0.02 & 0.239 & 0.00001 & 0.00001 \\
\hline
\end{tabular}

a.bMeans of a same factor, with different letters in a same row, differ between each other $(p<0.05)$. SEM = standard error of mean; ${ }^{1}$ Ossification: $A=$ carcasses exhibiting A00 to A99 overall maturity characteristics; B = carcasses exhibiting B00 to B99 overall maturity characteristic; ${ }^{2}$ Marbling: 1 = Practically devoid +; 2 : Traces =; 3: Slight - 


\section{Carcass characteristics}

The rib eye area (REA) was not affected by the production system or the treatments $\left(\sim 66.7 \mathrm{~cm}^{2} ; p>\right.$ $0.05)$. More significant values $(p<0.05)$ of dressing percentage (DP) were observed in the Semi-feedlot experiment when compared to animals in the Pasture group. On the other hand, no effect of DP was observed between the treatments. The physiological maturity of carcasses revealed that animals in the Semi-feedlot experiment were younger $(p<0.05)$ than those of the Pasture group. The non-castrated animals, in turn, were older $(p<0.05)$ than the immunocastrated ones, supplied or not with lasalocid.

Significant effects were observed in the interaction between the production systems and the types of treatment regarding Hot Carcass Weight (HCW), Subcutaneous Fat Thickness (FT), Marbling Level, and ultimate $\mathrm{pH}$ of the Longissimus muscle (Table 1). Differences were not observed for HCW in the treatments $(p>0.05)$ in the Semi-feedlot. In the Pasture system, the non-castrated males exhibited heavier carcasses than those immunocastrated, regardless of ionophore supplementation $(p>0.05)$. The immunocastrated animals supplied with lasalocid showed heavier carcasses $(p<0.05)$ in the Semi-feedlot system than those in the Pasture experiment. These results demonstrate that the effect of lasalocid was more efficient when the level of available energy was greater (Figure 1B).

The FT and the deposition of intramuscular fat (Marbling) were more prominent in the two groups of immunocastrated animals than in the group of noncastrated males, only in the Pasture experiment. In the Semi-feedlot system, no difference was observed between the treatments (Figure 1C). The immunocastrated animals, without lasalocid supplementation, showed a higher deposition rate $(p<0.05)$ of FT when finished at Pasture than those in the Semi-feedlot group. Regarding the marbling levels, the two groups of immunocastrated animals displayed higher deposition when in the Pasture system when compared with those in the Semi-feedlot. On the other hand, the production system did not affect fat deposition in the non-castrated males (Figure 1D). Differences inherent to animal selection at the beginning of the Pasture and Semi-feedlot experiments may have contributed to the observed distinctions regarding fat deposition in the immunocastrated animals, with and without lasalocid supplementation.
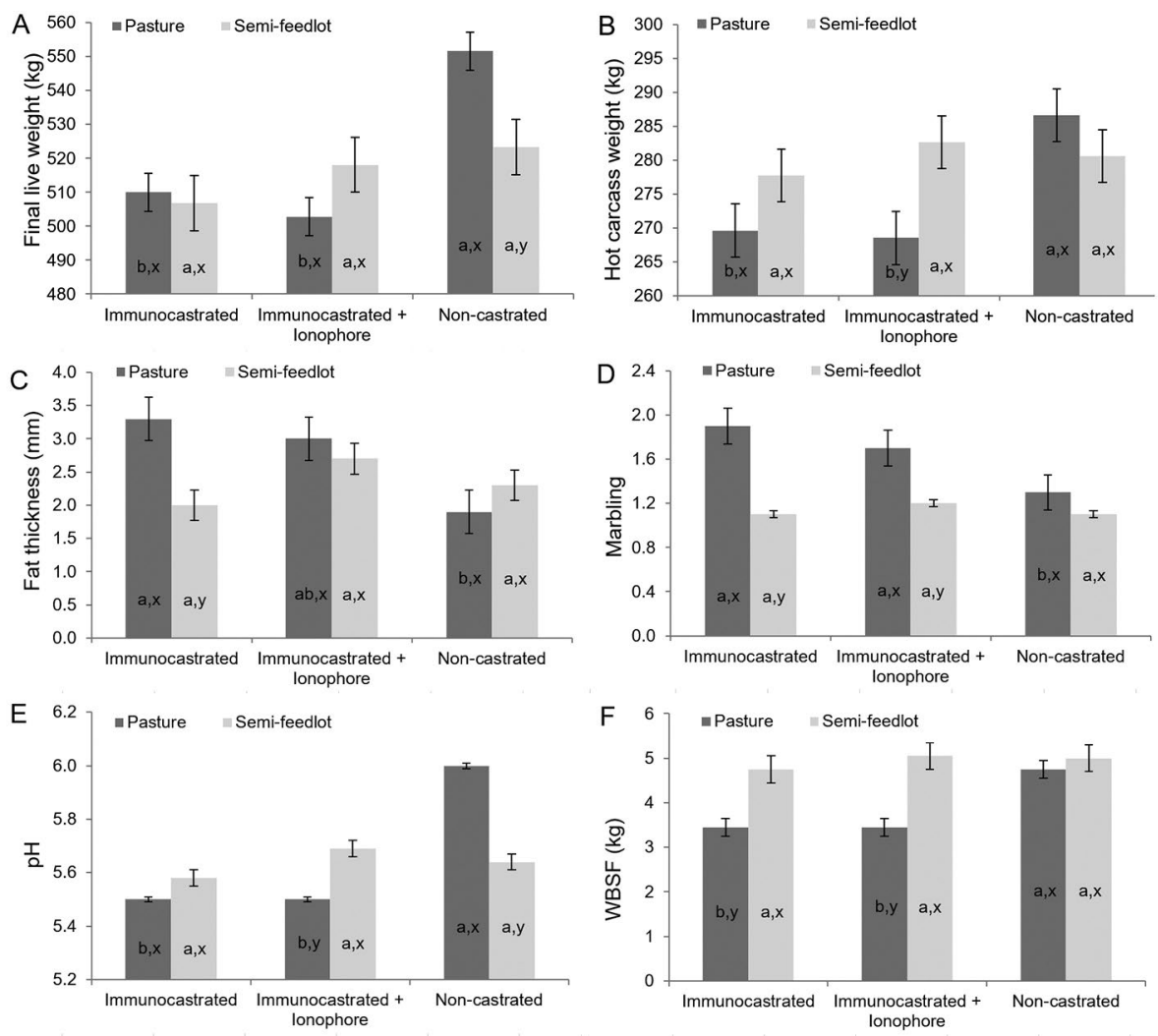

Figure 1 - Interaction between the production system and type of treatment regarding (A) final live weight, (B) hot carcass weight, (C) subcutaneous fat thickness, (D) Marblimg Level, (E) ultimate pH, and (F) Warner Bratzler shear force. a,bifferent letters, for the same production system, differ between each other $(p<0.05)$. xyDifferent letters, for the same type of treatment, differ between each other $(p<0.05)$. Marbling: 1 : Practically devoid +; 2: Traces =; 3: Slight-. 
Effects of the treatments on the final $\mathrm{pH}$ values were not observed in the animals finished in the Semifeedlot system $(p>0.05)$. However, the non-castrated males finished at Pasture displayed higher $\mathrm{pH}$ values than those that were castrated (Figure 1E). In the group of animals finished at Pasture, the non-castrated males exhibited $23 \%$ of Dark Cutting Beef $(\mathrm{pH} \geq 5.90)$, whereas this phenomenon was not observed in the castrated animals, supplied or not with lasalocid. In turn, the incidence of Dark Cutting Beef was low and similar between the three treatments (Table 2).

The remaining beef quality attributes were evaluated only in the samples that displayed $\mathrm{pH}$ lower than 5.90, since meat with high $\mathrm{pH}$ is considered Dark Cutting Beef, which interferes directly on the water retention capacity and, consequently, other characteristics of the product. Thus, nine samples of non-castrated males were excluded from the Pasture experiment. Sample from the Immunocastrated $(\mathrm{n}=$ 1), Immunocastrated supplied with lasalocid ( $\mathrm{n}=2)$, and Non-castrated animal $(\mathrm{n}=1)$ groups were removed from the Semi-feedlot experiment.

\section{Meat quality}

An effect $(p>0.05)$ was not observed in the interaction between the production system and types of treatment regarding the moisture and fat contents of the Longissimus muscle. However, the samples from Pasture animals exhibited more significant $(p<0.05)$ moisture content than those from the Semi-feedlot group. The samples of immunocastrated animals, which received ionophore or not, showed higher lipid contents and lower moisture levels than those of non-castrated animals $(p<0.05)$. The lipid contents corroborate the visual evaluation values of the marble levels described previously (Table 3).

The samples of the immunocastrated animals that were supplied with lasalocid and finished at Pasture retained higher values for $\mathrm{a}^{*}$ than those finished in the Semi-feedlot, not differing in terms of $\mathrm{L}^{*}$ and $\mathrm{b}^{*}$ variables. Samples of the non-castrated animals finished at Pasture showed more significant values for $\mathrm{a}^{*}$ and $\mathrm{b}^{*}$, and lower values of $\mathrm{L}^{*}$, than those finished in Semi-feedlot. There were differences in the beef color attributes between the treatments only in the Pasture experiment. The samples of the non-castrated animals exhibited greater values for $a^{*}$ and $b^{*}$, and lower $L^{*}$ values, than the samples from those that were immunocastrated, with lasalocid added or not, and did not differ from each other (Table 3).

The cooking loss was not affected by the Production System, Treatments, or aging period $(p>$ 0.05; Table 4). A significant effect was observed in the interaction between the production system and the type of treatment, and between the production system and aging period, regarding the values of instrumental tenderness (Table 4). In the Pasture experiment, the samples that aged for 7 or $14 \mathrm{~d}$, from the non-castrated animals, were higher $(p<0.05)$ concerning shear force than those of the immunocastrated animals, supplied or not with lasalocid. In the Semi-feedlot experiment, no differences were observed regarding instrumental tenderness in the treatments for samples that aged for 7 or $14 \mathrm{~d}(p>0.05)$. The values were generally higher than in the Pasture experiment (Figure $1 \mathrm{~F}$ ).

The longer aging period improved $(p<0.05)$ tenderness only in the samples from the Semi-feedlot experiment. Furthermore, the samples from the pasturegrazed animals were tenderer $(p<0.05)$ than those

Table 2 - Incidence of dark cutting beef $(\mathrm{pH}>5.90)$ per production system and type of treatment.

\begin{tabular}{|c|c|c|c|c|c|}
\hline & & Immunocastrated & Immunocastrated + Ionophore & Non-castrated & Total \\
\hline \multirow{2}{*}{ Pasture } & $\mathrm{pH}<5.89$ & $20(51 \%)$ & $20(50 \%)$ & $11(27 \%)$ & $51(85 \%)$ \\
\hline & $\mathrm{pH}>5.90$ & $0(0 \%)$ & $0(0 \%)$ & $9(23 \%)$ & $9(15 \%)$ \\
\hline \multirow{2}{*}{ Semi-feedlot } & $\mathrm{pH}<5.89$ & $18(46 \%)$ & $18(45 \%)$ & $19(47 \%)$ & $55(93 \%)$ \\
\hline & $\mathrm{pH}>5.90$ & $1(3 \%)$ & $2(5 \%)$ & $1(3 \%)$ & $4(7 \%)$ \\
\hline \multirow{2}{*}{ Total } & $\mathrm{pH}<5.89$ & $38(97 \%)$ & $38(95 \%)$ & $30(75 \%)$ & $106(89 \%)$ \\
\hline & $\mathrm{pH}>5.90$ & $1(3 \%)$ & $2(5 \%)$ & $10(25 \%)$ & $13(11 \%)$ \\
\hline
\end{tabular}

Table 3 - Effect of the beef production system and type of treatment on the visual and instrumental color of the meat, except for samples with $\mathrm{pH}$ equal or superior to 5.9 .

\begin{tabular}{|c|c|c|c|c|c|c|c|c|c|}
\hline & \multicolumn{2}{|c|}{ Production system } & \multicolumn{3}{|c|}{ Treatment } & \multirow[b]{2}{*}{ SEM } & \multicolumn{3}{|c|}{$p$ value } \\
\hline & Pasture & Semi-feedlot & Immunocastrated & $\begin{array}{l}\text { Immunocastrated + } \\
\text { lonophore }\end{array}$ & Non-castrated & & $\begin{array}{c}\text { Production } \\
\text { system }\end{array}$ & Treatment & $\begin{array}{c}\text { Prod. System } \times \\
\text { Treatment }\end{array}$ \\
\hline Moisture \% & $75.1^{\mathrm{a}}$ & $73.8^{b}$ & $74.4^{b}$ & $74.2^{b}$ & $74.8^{a}$ & 0.1 & 0.000001 & 0.00002 & 0.376 \\
\hline Fat $\%$ & 2.2 & 2.0 & $2.2^{\mathrm{a}}$ & $2.2^{\mathrm{a}}$ & $1.8^{\mathrm{b}}$ & 0.1 & 0.721 & 0.033 & 0.077 \\
\hline L & $35.5^{\mathrm{b}}$ & $38.3^{\mathrm{a}}$ & $37.9^{\mathrm{a}}$ & $38.3^{\mathrm{a}}$ & $34.1^{\mathrm{b}}$ & 0.5 & 0.00001 & 0.00001 & 0.00001 \\
\hline$a$ & $21.7^{\mathrm{a}}$ & $17.8^{\mathrm{b}}$ & $18.9^{b}$ & $18.4^{\mathrm{b}}$ & $22.3^{\mathrm{a}}$ & 0.4 & 0.00001 & 0.00001 & 0.00001 \\
\hline$b$ & $17.9^{\mathrm{a}}$ & $15.0^{\mathrm{b}}$ & $15.6^{b}$ & $15.0^{\mathrm{b}}$ & $19.2^{\mathrm{a}}$ & 0.4 & 0.00001 & 0.00001 & 0.00001 \\
\hline
\end{tabular}

a, bMeans of a same factor, with different letters in a same row, differ between each other $(p<0.05)$. SEM = standard error of mean. "L" for the lightness from black $(0)$ to white (100), "a" from green $(-60)$ to red $(+60)$, and "b" from blue $(-60)$ to yellow $(+60)$. 
from animals finished in Semi-feedlot, both at 7 and $14 \mathrm{~d}$ of aging. The animals in the Pasture experiment retained more subcutaneous and intramuscular fat than those in the Semi-feedlot group, even with feed shortages that occurred at the end of animal finishing. This more significant amount of fat may have favored beef tenderness, with $7 \mathrm{~d}$ of aging. Thus, the samples underwent less effect when the meat was aged for 14 d. In turn, in the Semi-feedlot, although the initial meat toughness was more prominent, aging for $14 \mathrm{~d}$ improved tenderness (Figure 2).

In the Pasture experiment, $14 \mathrm{~d}$ of aging were sufficient to make $100 \%$ of the samples of the immunocastrated animals tender (WBSF $\leq 4.4 \mathrm{~kg}$ ), whether or not supplemented with lasalocid. However, during this period, only $55 \%$ of the samples from the

Table 4 - Cooking loss and Warner-Bratzler shear force (WBSF), according to the beef production system, treatment, and aging period, except for samples with $\mathrm{pH}$ equal or superior to 5.9.

\begin{tabular}{|c|c|c|c|}
\hline & & Cooking loss, $\%$ & WBSF, kg \\
\hline \multirow{2}{*}{$\begin{array}{l}\text { Production system } \\
\text { (P. System) }\end{array}$} & Pasture & 21.7 & $3.8^{b}$ \\
\hline & Semi-feedlot & 21.8 & $4.9^{\mathrm{a}}$ \\
\hline \multirow{3}{*}{ Treatment } & Immunocastrated & 21.9 & $4.1^{\mathrm{b}}$ \\
\hline & $\begin{array}{l}\text { Immunocastrated + } \\
\text { lonophore }\end{array}$ & 21.4 & $4.2^{\mathrm{b}}$ \\
\hline & Non-castrated & 21.9 & $4.9^{\mathrm{a}}$ \\
\hline \multirow{2}{*}{ Aging Period } & 7 days & 22.0 & $4.6^{\mathrm{a}}$ \\
\hline & 14 days & 21.5 & $4.1^{\mathrm{b}}$ \\
\hline \multicolumn{2}{|l|}{ SEM } & 0.2 & 0.1 \\
\hline \multirow{7}{*}{$p$ value } & P. System & 0.86 & 0.000001 \\
\hline & Treatment & 0.14 & 0.000001 \\
\hline & Aging & 0.075 & 0.00019 \\
\hline & P. System $\times$ Treat & 0.40 & 0.00014 \\
\hline & P. System $\times$ Aging & 0.78 & 0.04 \\
\hline & Treatment $\times$ Aging & 0.51 & 0.74 \\
\hline & $\begin{array}{l}\text { P. System } \times \text { Treat } \\
\times \text { Aging }\end{array}$ & 0.43 & 0.90 \\
\hline
\end{tabular}

a,bMeans with different letters in a same column (Production System and Treatment) differ between each other $(p<0.05)$. SEM $=$ standard error of mean.

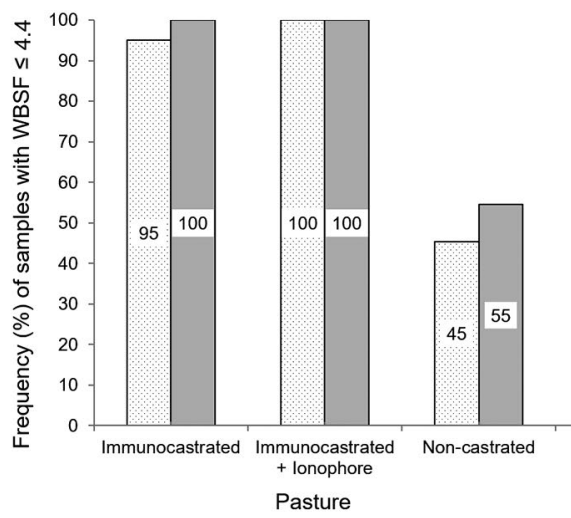

non-castrated animals were tender. In the Semi-feedlot system, $61 \%$ of the samples from the immunocastrated animals without ionophore supplementation, and $58 \%$ of the samples from non-castrated animals were tender after $14 \mathrm{~d}$ of aging. In turn, only $39 \%$ of the samples from the immunocastrated animals supplemented with ionophore were considered tender after the same period (Figure 3).

\section{Discussion}

\section{Animal performance}

Regarding the final live weight (FLW) variable, the interaction between the production system and the type of treatment showed that the pasture-grazed cattle had better weight gain when they were intact (Figure 1). Due to the presence of protein-energetic supplementation in the Semi-feedlot system, the castrated animals displayed similar performance to non-castrated ones, in contrast with what occurred in the Pasture group (without supplementation), with more weight gain for

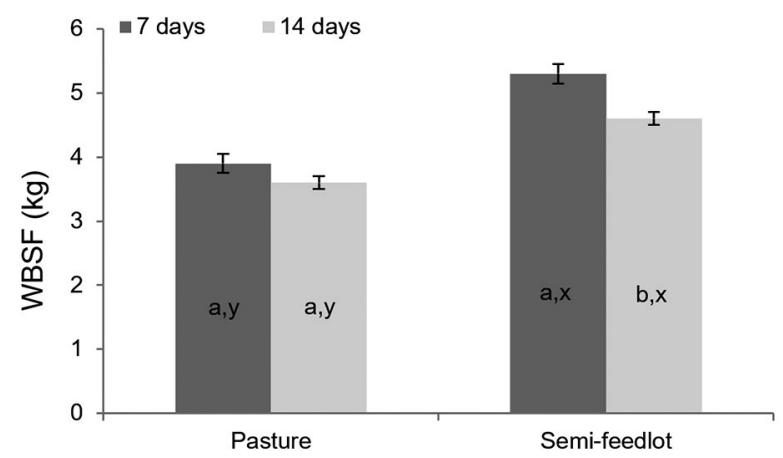

Figure 2 - Interaction between the production system and the aging period regarding the Warner Bratzler shear force (WBSF) of the Longissimus thoracis et lumborum muscle. ${ }^{\mathrm{a}, \mathrm{b}}$ Different letters, for the same production system, differ between each other $(p<0.05)$. $x, y$ Different letters, for the same aging period, differ between each other $(p<0.05)$.

$\square 7$ days $\quad \square 14$ days

Figure 3 - Interaction between the production system and the aging period regarding the Warner Bratzler shear force (WBSF) of the Longissimus thoracis et lumborum muscle. 
the non-castrated animals. It can be suggested that supplementation with concentrate at a ratio of $1 \%$ of body weight, associated with low-quality pastures due to the dry season, did not lead to greater weight gain, which would increase the final weight of both non-castrated and ionophore-treated animals. In other words, the feed restriction was so significant that the animals submitted to both treatments could not express their true potential for weight gain.

Lower weight gain for immunocastrated animals were described when compared with non-castrated cattle, and this difference was more pronounced during the finishing phase (Cook et al., 2000). The authors attribute this difference to lower feed intake by the immunocastrated group. In turn, Adams et al. (1996) did not verify differences in feed consumption in immunocastrated or control cattle, even though the authors reported more significant weight gain in the control group. AmatayakulChantler et al. (2013) stated that higher weight gains were observed in immunocastrated animals when compared with surgically castrated ones.

No differences regarding FLW was observed when animals were supplemented with monensin or with two concentrations of lasalocid (20.0 and $30.0 \mathrm{mg} \mathrm{kg}^{-1}$ ) when compared with the control group (Barreras et al., 2013). However, the authors reported a more significant DWG for animals that received lasalocid at a concentration of $30.0 \mathrm{mg} \mathrm{kg}^{-1}$ when compared with cattle that had not been supplemented with ionophores. The average DM intake was 7.55 and $7.77 \mathrm{~kg} \mathrm{~d}^{-1}$, and the lasalocid intake was 151 and $233 \mathrm{mg}$ per animal $\mathrm{d}^{-1}$ for the treatments with 20.0 and $30.0 \mathrm{mg} \mathrm{kg}^{-1}$, respectively. In this study, the animals from the Pasture experiment consumed an average of $175 \mathrm{mg} \mathrm{d}^{-1}$ of lasalocid, while in the Semifeedlot, the average consumption was of $240.2 \mathrm{mg}$ per animal $\mathrm{d}^{-1}$, similar to values reported by Barreras et al. (2013), in which the animals obtained greater weight gain than the control group (30.0 $\left.\mathrm{mg} \mathrm{kg}^{-1}\right)$. Increased DWG and feed efficiency caused by lasalocid supplementation have been described in the literature (Zinn, 1987). On the other hand, Sartori et al., 2017, when studying the growth of pasture-grazed heifers supplemented or not with lasalocid, with an average mineral salt intake of $0.180 \mathrm{~kg} \mathrm{~d}^{-1}$ and $216 \mathrm{mg} \mathrm{d}^{-1}$ of lasalocid, similar to the values in our study, did not observe an increase in weight gain of the animals. However, the authors reported that the body condition score was more pronounced in the group that consumed lasalocid.

\section{Carcass characteristics}

In relation to the rib eye area (REA), similar results were described by Miguel et al. (2014) when comparing non-castrated, immunocastrated, and surgically neutered cattle. Other authors have reported that immunocastration decreases rib eye area when compared to non-castrated animals (Ribeiro et al., 2004). Several authors have verified no differences regarding REA between animals supplemented or not with ionophores (Barreras et al., 2013; Zinn, 1987). Because of lower hormonal activity in immunocastrated males (Pérez-Linares et al., 2017), a smaller increase in muscle deposition was expected, with a consequent reduction in REA. However, this effect may not have occurred since the immunocastration was performed in adult animals, when muscle development is already more prominent. According to Arthaud et al. (1977), non-castrated animals are more physiologically mature than castrated ones, regarding the same chronological age, which is in agreement with the results observed in this study, where the non-castrated animals were significantly older.

As for the FLW, the food shortage that occurred in pasture might have favored the non-castrated animals, providing them greater HCW than to the immunocastrated ones. Cook et al. (2000) reported similar results. However, Perez et al. (2017) obtained higher values of hot carcass weight in immunocastrated animals when compared to non-castrated cattle. In turn, Miguel et al., 2014 and Amatayakul-Chantler et al. (2012) did not observe differences regarding HCW when comparing immunocastrated and non-castrated animals finished in feedlot. Concerning lasalocid supplementation, the results of our study are in accordance with those obtained by McMeniman et al. (1996), who reported no increase in HCW of animals supplemented with the studied ionophore.

The more significant deposition of subcutaneous and intramuscular fat in the meat samples of immunocastrated animals, when compared to noncastrated males, is consistent with the results described by several authors (D'Occhio et al., 2001; AmatayakulChantler et al., 2012; Andreo et al., 2013; Andreo et al., 2016; Freitas et al., 2015). Barreras et al. (2013) did not observe differences in FT deposition and marbling levels in animals that were treated or not with lasalocid. However, McMeniman et al. (1996) reported higher deposition of subcutaneous and intramuscular fat in lasalocid-treated animals, when compared to control animals. Decreased blood testosterone levels may lead to increased deposition of adipose tissue, which can occur by the accumulation of visceral, subcutaneous, and intramuscular fat.

Higher $\mathrm{pH}$ values in non-castrated animals was obtained when compared with immunocastrated or surgically castrated ones (Miguel et al., 2014). Due to their temperament, non-castrated animals are more susceptible to the depletion of muscle glycogen than castrated bovines. This decrease in glycogen reserves leads to lower production of lactic acid, resulting in higher $\mathrm{pH}$ values. On the other hand, Pérez-Linares et al. (2017) did not observe effects regarding $\mathrm{pH}$ when comparing non-castrated or immunocastrated animals. The treatment with lasalocid did not affect the final $\mathrm{pH}$ of meat and the values were within the normal range (Wulf et al., 2002). Similar results were verified by Gilka et al. (1989) when comparing the $\mathrm{pH}$ levels of lamb meat, treated or not with lasalocid. 


\section{Meat quality}

More substantial frequency of carcasses classified as USDA Choice (higher levels of intramuscular fat) was observed in animals that were immunocastrated when compared to non-castrated animals (AmatayakulChantler et al., 2012). In addition, Andreo et al. (2013) reported higher lipid content and lower moisture levels in meat samples from immunocastrated animals when compared to non-castrated ones. Gilka et al. (1989) did not observe differences in moisture and intramuscular fat content between samples of lambs that received monensin or lasalocid.

Higher $\mathrm{L}^{*}$ values in samples from non-castrated animals were described when compared to those from immunocastrated ones (Miguel et al., 2014). The authors attributed this difference to the greater $\mathrm{pH}$ values of the non-castrated group, which promotes increased the mitochondrial activity for oxygen consumption, masking bloom development, resulting in a dark appearance (Ashmore et al., 1973). According to Seideman et al. (1982), castration, surgical or immunological, could be an effective tool to reduce dark meat, which is usually observed in non-castrated males. In contrast, Costa et al. (2007) did not find differences between castrated or non-castrated animals regarding the $\mathrm{L}^{*}$ variable.

Regarding variables a* and b*, Miguel et al. (2014) reported lower values for samples from non-castrated animals when compared with immunocastrated ones. In turn, Pérez-Linares et al. (2017) did not observe differences in the instrumental color variables from samples of castrated or non-castrated animals. Andreo et al. (2013) described higher values of $a^{*}$ and $b^{*}$ in meat from immunocastrated animals. The authors associated this result to the higher levels of intramuscular fat. Few studies have evaluated the effect of ionophore on meat color. Gomes et al. (2009) did not observe changes in $\mathrm{L}^{*}, \mathrm{a}^{*}$, and $\mathrm{b}^{*}$ in cattle supplemented with monensin when compared with control animals.

Other authors also have not reported differences in cooking loss between samples of immunocastrated and non-castrated animals (Andreo et al., 2013; Miguel et al., 2014; Costa et al., 2007; Ribeiro et al., 2004). Gomes et al. (2009) did not observe any effect regarding the use of monensin ionophore on cooking loss when compared with animals without supplementation of the substance. Andreo et al. (2013) also stated that meat from non-castrated cattle is tougher than that from immunocastrated animals. The greater tenderness of meat from immunocastrated animals may have been favored by the higher degree of finishing and intramuscular fat content. According to Felício (1997), carcasses that are poorly covered with subcutaneous fat are more subject to cold shortening, which results in meat toughening. Other authors have reported that meat from surgically castrated animals is usually tender than that from non-castrated ones (Costa et al., 2007; Dikeman et al., 1986).
In the Semi-feedlot experiment, differences were not observed regarding instrumental tenderness in the treatments for the samples that were aged for 7 or 14 $\mathrm{d}(\sim 5.3 \pm 0.4 \mathrm{~kg}$ and $4.5 \pm 0.2 \mathrm{~kg}$, respectively; $p>$ $0.05)$, with values that were generally higher than in the Pasture group. Similar results were described by Perez et al. (2017), who also found no difference in tenderness between samples from immunocastrated and non-castrated animals. Accordingly, Miguel et al. (2014) reported no difference in tenderness between immunocastrated and non-castrated animals. However, these authors observed a higher incidence of dark, firm, and dry (DFD) meat in the samples of noncastrated cattle, which, in some conditions, may favor tenderness due to high water retention capacity and more significant enzymatic activity (Beltrán et al., 1997). Regarding the use of lasalocid, Gilka et al. (1989) also found no differences concerning instrumental tenderness, evaluated by penetrometer, nor for sensorial tenderness, in samples of lamb that were treated or not with lasalocid or monensin.

\section{Conclusion}

The non-castrated animals displayed improved performance regarding live weight and carcass gains than those that were immunocastrated, especially when they were finished at pasture. However, a higher incidence of dark cutting was observed, as well as a greater frequency of tough meat in non-castrated animals. The use of lasalocid was not sufficient to offset the lower performance of the immunocastrated animals and did not affect meat quality indicators. Thus, it can be concluded that, despite an effect on animal growth, immunocastration is an excellent alternative for producing better quality meat, since it presents higher marbling, lower incidence of dark cutting, and tenderer meat, regardless of the production system or ionophore supplementation.

\section{Acknowledgements}

The authors thank the Brazilian National Council for Scientific and Technological Development (CNPq) for providing the financial support for scholarship.

\section{Authors' Contributions}

Conceptualization, Data acquisition, Data analysis and Writing and editing: Jacinto-Valderrama, R.A.; Sampaio, G.S.L.; Lima, M.L.P.; Cyrillo, J.N.S.G.; Pflanzer, S.B.

\section{References}

Adams, T.E.; Daley, C.A.; Adams, B.M.; Sakurai, H. 1996. Testes function and feedlot performance of bulls actively immunized against gonadotropin-releasing hormone: effect of age at immunization. Journal of Animal Science 74: 950-954. 
Amatayakul-Chantler, S.; Hoe, F.; Jackson, J.A.; Roca, R.O.; Stegner, J.E.; King, V.; Howard, R. 2013. Effects on performance and carcass and meat quality attributes following immunocastration with the gonadotropin releasing factor vaccine Bopriva or surgical castration of Bos indicus bulls raised on pasture in Brazil. Meat Science 95: 78-84.

Amatayakul-Chantler, S.; Jackson, J.A.; Stegner, J.; King, V.; Rubio, L.M.S.; Howard, R.; Lopez, E.; Walker, J. 2012. Brown Swiss bulls in a feedlot with the Bos indicus immunocastration of gonadotropin-releasing hormone vaccine Bopriva provides improved performance and meat quality. Journal of Animal Science 90: 3718-3728.

American Meat Science Association [AMSA]. 1991. Guidelines for Meat Color Evaluation. AMSA, Chicago, IL, USA.

American Meat Science Association [AMSA]. 2001. Meat Evaluation Handbook: Beef Grading. AMSA, Chicago, IL, USA.

American Meat Science Association [AMSA]. 2015. Research Guidelines for Cookery, Sensory Evaluation and Tenderness Measurements of Meat. AMSA, Champaign, IL, USA.

Andreo, N.; Bridi, A.M.; Soares, A.L.; Prohmann, P.E.F.; Peres, L.M.; Tarsitano, M.A.; Takabayashi, A.A. 2016. Fatty acid profile of beef from immunocastrated (BOPRIVA ${ }^{\circledR}$ ) Nellore bulls. Meat Science 117: 12-17.

Andreo, N.; Bridi, A.M.; Tarsitano, M.A.; Peres, L.M.; Costa Barbon, A.P.A.; Andrade, E.L.; Prohmann, P.E.F. 2013. Influence of immunocastration (Bopriva ${ }^{\circledR}$ ) on weight gain, carcass characteristics and beef quality of Nellore cattle. Semina: Ciências Agrárias 34: 4121-4132 (in Portuguese, with abstract in English).

Association of Official Analytical Chemists [AOAC]. 1980. Official Method of Analysis of the Association of Analytical Chemists, AOAC, Rockville, MD, USA.

Arthaud, V.H.; Mandigo, R.W.; Koch, R.M.; Kotula, A.W. 1977. Carcass composition, quality and palatability attributes of bulls and steers fed different energy levels and killed at four ages. Journal of Animal Science 44: 53-64.

Ashmore, C.R.; Carroll, F.; Doerr, L.; Tompkins, G.; Stokes, H.; Parker, W. 1973. Experimental prevention of dark-cutting meat. Journal of Animal Science 36: 33-36.

Barreras, A.; Castro-Pérez, B.I.; López-Soto, M.A.; Torrentera, N.G.; Montaño, M.F.; Estrada-Ângulo, A.; Ríos, F.G.; DávilaRamos, H.; Plascencia, A.; Zinn, R.A. 2013. Influence of ionophore supplementation on growth performance, dietary energetics and carcass characteristics in finishing cattle during period of heat stress. Asian Australasian Journal of Animal Science 26: 1553-1561.

Beltrán, J.A.; Jaime, I.; Santolaria, P.; Sañudo, C.; Albertí, P. 1997. Effect of Stress-induced high post-mortem $\mathrm{pH}$ on protease activity and tenderness of beef. Meat Science 45: 200-205.

Bligh, E.G.; Dyer, W.J. 1959. A rapid method of total lipid extraction and purification. Canadian Journal of Biochemistry and Physiology 37: $911-917$.

Cook, R.B.; Popp, J.D.; Kastelic, J.P.; Robbins, S.; Harland, R. 2000. The effects of active immunization against $\mathrm{GnRH}$ on testicular development, feedlot performance, and carcass characteristics of beef bulls. Journal of Animal Science 78: 2778-2783.
Costa, C.; Meirelles, P.R.L.; Savastano, S.; Arrigoni, M.B.; Silveira, A.C.; Roça, R.O.; Mourão, G.B. 2007. Effect of castration on the quality of meat of young cattle. Veterinária e Zootecnia 14: 115-123 (in Portuguese, with abstract in English).

Dikeman, M.E.; Redd, G.B.; Arthaud, V.H.; Tuma, H.J.; Koch, R.M.; Mandigo, R.W.; Axe, J.B. 1986. Longissimusmuscle quality, palatability and connective tissue histological characteristics of bulls and steers fed different energy levels and slaughtered at four ages. Journal of Animal Science 63: 92-101.

D'Occhio, M.J.; Aspden, W.J.; Trigg, T.E. 2001. Sustained testicular atrophy in bulls actively immunized against GnRH: potential to control carcass characteristics. Animal Reproduction Science 66: 47-58.

Felício, P.E. 1997. Ante and post-mortem factors influencing the quality of beef. p. 79-97. In: Peixoto, A.M.; Moura, J.C.; Faria, V.P., eds. Beef cattle production. FEALQ, Piracicaba, SP, Brazil (in Portuguese, with abstract in English).

Freitas, V.M.; Leão, K.M.; Araujo Neto, F.R.; Marques, T.C.; Ferreira, R.M.; Garcia, L.L.F.; Oliveira, E.B. 2015. Effects of surgical castration, immunocastration and homeopathy on the performance, carcass characteristics and behaviour of feedlot-finished crossbred bulls. Semina: Ciências Agrárias. 36: $1725-1734$.

Gilka, J.; Jelínek, P.; Janková, B.; Krejčí, P.; Habrda, J. 1989. Carcass traits and meat quality of male lambs fed monensin or lasalocid. Meat Science 25: 265-272.

Gomes, R.C.; Leme, P.R.; Silva, L.S.; Antunes, M.T.; Guedes, C.F. 2009. Carcass quality of feedlot finished steers fed yeast, monensin, and the association of both additives. Arquivo Brasileiro de Medicina Veterinária e Zootecnia 61: 648-654.

McMeniman, N.; Elliott, R.; Hogden, A. 1996. The use of lasalocid in long-term feeding of Friesian steers. Australian Journal of Experimental Agriculture 36: 397-400.

Miguel, G.Z.; Faria, M.H.; Roça, R.O.; Santos, C.T.; Suman, S.P.; Faitarone, A.B.G.; Delbem, N.L.C.; Girao, L.V.C.; Homem, J.M.; Barbosa, E.K.; Su, L.S.; Resende, F.D.; Siqueira, G.R.; Moreira, A.D.; Savian, T.V. 2014. Immunocastration improves carcass traits and beef color attributes in Nellore and Nellore $\times$ Aberdeen Angus crossbred animals finished in feedlot. Meat Science 96: 884-891.

Ministério da Agricultura, Pecuária e Abastecimento [MAPA]. 2004. Brazilian System of Beef Carcass Grading (Normative Instruction, 9) = Sistema Brasileiro de Classificação de Carcaças de Bovinos. (Instrução Normativa, 9). MAPA, Brasília, DF, Brazil.

Needham, T.; Lambrechts, H.; Hoffman, C. 2017. Castration of male livestock and the potential of immunocastration to improve animal welfare and production traits: invited review. South African Journal of Animal Science 47: 6-10.

Pérez-Linares, C.; Bolado-Sarabia, L.; Figueroa-Saavedra, F.; Barreras-Serrano, A.; Sánchez-López, E.; Tamayo-Sosa, A.R.; Godina, A.A.; Ríos-Rincón, F.; García, L.A.; Gallegos, E. 2017. Effect of immunocastration with Bopriva on carcass characteristics and meat quality of feedlot Holstein bulls. Meat Science 123: 45-49. 
Ribeiro, E.L.A.; Hernandez, J.A.; Zanella, E.L.; Shimokomaki, M.; Prudêncio-Ferreira, S.H.; Youssef, E.; Ribeiro, H.J.S.S.; Bogden, R.; Reeves, J.J. 2004. Growth and carcass characteristics of pasture fed LHRH immunocastrated, castrated and intact Bos indicus bulls. Meat Science 68: 285290.

Russel, J.B.; Strobel, H.J. 1989. Effect of lonophores on Ruminal fermentation. Applied and Environmental Microbiology 55: $1-6$.

Sartori, E.D.; Canellas, L.C.; Pereira, G.R.; Moojen, F.G.; Carvalho, H.R.; Barcellos, J.O.J. 2017. Performance of beef heifers supplemented with sodium lasalocid. Tropical Animal Health and Production 49: 273-279.
Seideman, S.C.; Cross, H.R.; Oltjen, R.R.; Scjanbacher, B.D. 1982. Utilization of the intact male for red meat production. Journal of Animal Science 55: 826-840.

Wulf, D.M.; Emnett, R.S.; Leheska, J.M.; Moeller, S.J. 2002 Relationships among glycolytic potential, dark cutting (dark, firm, and dryl beef, and cooked beef palatability. Journal of Animal Science 80: 1895-1903.

Zinn, R.A. 1987. Influence of lasalocid and monensin plus tylosin on comparative feeding value of steam-flaked versus dryrolled corn diets for feedlot cattle. Journal of Animal Science 65: 256-266. 